\title{
KOMPARASI HASIL BELAJAR SISWA ANTARA MODEL MAKE A MATCH DENGAN MODEL JIGSAW PADA MATA PELAJARAN GEOGRAFI KELAS $X$ IPS DI SMAN 3 BATUSANGKAR
}

\author{
Tri Perra Paula Tama ${ }^{1}$, Nofrion ${ }^{2}$ \\ Program Studi Pendidikan Geografi \\ Fakultas Ilmu Sosial, Universitas Negeri Padang \\ Email : perrapaula@gmail.com
}

\begin{abstract}
Abstrak
Jenis penelitian ini adalah Eksperimen dengan populasi penelitian seluruh kelas X SMA N 3 Batusangkar yang terdaftar pada tahun ajaran 2017/2018. Teknik pengambilan sampel yang digunakan Total Sampling. Penelitian ini dilakukan di SMA N 3 Batusangkar. Hipotesis penelitian di uji dengan uji t-test pada taraf nyata $0,05 \mathrm{dan} d \mathrm{dk}=48$, sebelum menggunakan uji t-test dilakukan uji prasyaratan analisis yaitu uji Normalitas dan Homogenitas. Berdasarkan hasil analisis data penelitian menunjukkan bahwa kelas yang menggunakan model pembelajaran Make A Match memiliki rata-rata hasil belajar 84,28 dan kelas yang menggunakan model Jigsaw memiliki rata-rata hasil belajar 77,2. Dari hasil uji beda kedua kelas diperoleh t hitungsebesar 3,293 > t tabel 2.021 pada taraf signifikan 0,05 dengan demikian hipotesis kerja Hi dapat diterima. Hal ini dapat disimpulkan bahwa terdapat perbedaan yang signifikan antara hasil belajar siswa dengan menggunakan model pembelajaran Make A Match dengan Model Jigsaw.
\end{abstract}

Kata Kunci : Hasil Belajar, Model Make A Match, Model Jigsaw

\begin{abstract}
The type of this research is experiment, with research population is all class $X$ SMA $N 3$ Batusangkar registered in academic year 2017/2018. Sampling technique used Total Sampling. This research was conducted in SMA $N 3$ Batusangkar. The research hypothesis was tested by $t$-test at the real level of 0.05 and $d k=48$, before using the t-test test, it was tested by the pre-tested test that is the normality and homogeneity test. Based on the results of data analysis showed that the class that uses the Make A Match learning model has an average learning outcome of 84.28 and the class using the Jigsaw model has an average learning outcome of 77.2. From the results of different test the two classes obtained t arithmetic of 3.293> t table 2.021 at a significant level of 0.05 thus $\mathrm{Hi}$ working hypothesis acceptable. It can be concluded that there is a significant difference between student learning outcomes by using the model of Make A Match learning with Jigsaw Model.
\end{abstract}

Keywords: Learning Outcomes, Make A Match Model, Jigsaw Model

${ }^{1}$ Mahasiswa Program Studi Pendidikan Geografi untuk Wisuda Maret 2018

Jurusan Geografi Fakultas Ilmu Sosial Universitas Negeri Padang

${ }^{2}$ Dosen Program Studi Pendidikan Geografi, Dosen Pembimbing 1.Drs.Surtani,M.Pd,Pembimbing 2.

Nofrion,S.Pd,M.Pd 


\section{PENDAHULUAN}

$\begin{array}{cccc} & \text { Pendidikan merupakan } & \text { faktor } \\ \text { yang } & \text { sangat } & \text { penting } & \text { dalam }\end{array}$
meningkatkan kualitas sumber daya manusia suatu bangsa. Berdasarkan Undang-undang No.20 tahun 2003 pasal 1 ayat (1) tentang Sistem Pendidikan Nasional menyatakan bahwa: Pendidikan adalah usaha sadar dan terencana untuk mewujudkan suasana belajar dan proses pembelajaran agar peserta didik secara aktif mengembangkan potensi dirinya untuk memiliki kekuatan spiritual, keagamaan, pengendalian diri, kepribadian, kecerdasan, akhlak mulia, serta keterampilan yang diperlukan dirinya, masyarakat,bangsa dan negara.

Berdasarkan pembukaan UndangUndang Dasar 1945 alinea IV yang menegaskan bahwa salah satu tujuan nasional bangsa Indonesia adalah mencerdaskan kehidupan bangsa. Untuk menghasilkan mutu pendidikan yang berkualitas maka dibutuhkan manusiamanusia yang memiliki pengetahuan, keterampilan, dan potensi yang nantinya dapat diharapkan menjadi pembawa perubahan dilingkungan masyarakat. Disinilah lembaga pendidikan memiliki peran atau tugas yang sangat penting dalam proses peningkatan mutu pemdidikan sehingga menghasilkan insan yang berkualitas dan siap berkontribusi demi kemajuan bangsa.

Guru mempunyai fungsi dan peran yang sangat strategis dalam pembangunan bidang pendidikan. Oleh karena itu, dibutuhkan tenaga pendidik yang professional (guru profesional). Guru profesional adalah mereka yang secara spesifik memiliki pekerjaan yang didasari oleh keahlian keguruan dengan pemahaman yang mendalam terhadap landasan kependidikan, dan secara akademis memiliki pengetahuan teoriteori kependidikan dan memiliki keterampilan mengimplementasikan teori kependidikan tersebut (Rusman, 2010:70).

Menurut Undang-undang No.14 tahun 2005 tentang Guru dan Dosen pasal 4 menegaskan bahwa: Guru sebagai agen pembelajaran berfungsi untuk meningkatkan mutu pendidikan nasional. Untuk dapat melaksanakan fungsinya dengan baik, guru wajib untuk memiliki syarat tertentu, salah satu diantaranya adalah Kompetensi.

Peran guru sangat dibutuhkan dalam proses belajar mengajar. Karena itu, dipundak guru terdapat tanggung jawab yang secara terus-menerus sampai akhir hayat. Besarnya kepercayaan masyarakat terhadap guru mendorong mereka untuk menyadari eksistensinya. Namun, akhir-akhir ini terjadi kesenjangan antara hasil pendidikan peserta didik dengan tuntutan masyarakat yang ingin anaknya berprestasi.

Menurut Mudjia Rahardjoyang dikutip(Napsiah (2016:2) mengatakan bahwa secara logis, setiap usaha pengembangan profesi harus bertolak dari kontruk profesi, untuk kemudian bergerak ke arah substansi spesifik bidangnya. Diletakkan dalam konteks pengembangan profesionalisme keguruan, setiap pembahasan konstruk profesi harus di ikuti dengan penemuan dan pengenalan muatan spesifik bidang keguruan. Guru bukan sekedar 
pekerjaan atau mata pencaharian yang membutuhkan keterampilan teknis, melainkan juga pengetahuan teoritis. Demikian dengan pekerjaan keguruan siapa saja bisa terampil mengajar orang lain, tetapi hanya mereka yang berbekal pendidikan profesional keguruan yang bisa menegaskan dirinya memiliki pemahaman teoritis bidang keahlian kependidikan.

Berdasarkan rata-rata hasil belajar siswa tersebut dapat diketahui bahwa masih banyak nilai yang dibawah Kriteria Ketuntasan Minimun (KKM). Guru biasanya menggunakan model pembelajaran Jigsaw dalam proses belajar mengajar. Namun Model Jigsaw belum meningkatkan pemahaman dan keaktifan peserta didik dilihat dari ratarata hasil belajar siswa tersebut maka perlu model belajar yang efektif dan efisien. Berdasarkan permasalahan di atas maka Penulis mencoba membandingkan hasil belajar dengan menggunakan Model Make A Match karena Model ini sangat menyenangkan dan membuat siswa bersemangat disebabkan adanya Gamesatau permainan dalam proses belajar mengajar.

Menurut Anita Lie (2004:55), Model Make A Match (mencari pasangan) adalah salah satu model pembelajaran kooperatif yang dikembangkan oleh Lorna Curran (1994). Sebuah model yang dapat merangsang kemauan peserta didik untuk belajar karena dilakukan dengan suasana yang menyenangkan. Model ini juga dapat digunakan pada semua mata pelajaran dan tingkatan usia siswa. Dalam pelaksaannya masing-masing siswa diberikan sebuah kartu yang berisi sebuah pertanyaan dan jawaban mengenai materi yang akan diajarkan. Kemudian peserta didik mencari pasangannya sesuai dengan apa yang tertulis pada kertu yang dimiliki. Dengan demikian membantu siswa menggali kembali pengetahuan yang sudah dimiliki dan menggabungkannya dengan pengetahuan yang baru. Teknik ini akan membuat siswa lebih memahami setiap materi yang disajikan oleh guru.Sehubungan dari uraian diatas,maka Peneliti ingin melakukan penelitian dengan mengambil judul tentang: "Komparasi Hasil Belajar Siswa Antara Model Make A Match Dengan Model Jigsaw Pada Mata Pelajaran Geografi Kelas X IPS SMA Negeri 3 Batusangkar". Tujuan penelitian ini adalah untuk mengetahui perbedaan hasil belajar siswa antara Model Make A Match dengan Model Jigsaw pada mata pelajaran Geografi Kelas $X$ IPS SMA Negeri 3 Batusangkar.

1. Belajar dan Pembelajaran

Belajar adalah suatu aktivitas atau suatu proses untuk memperoleh pengetahuan, meningkatkan keterampilan, memperbaiki perilaku, sikap, dan mengokohkan kepribadian. Witherington (1952) menyatakan bahwa belajar merupakan perubahan dalam kepribadian, yang dimanifestasikan sebagai pola-pola respon yang baru yang berbentuk keterampilan, sikap, kebiasaan, pengetahuan dan kecakapan. Belajar dikatakan berhasil jika seseorang mampu mengulang kembali materi yang 
telah dipelajarinya (Suyono, 2014: 912).

Proses belajar terdiri atas tiga tahapan, yaitu tahap informasi, transformasi, dan evaluasi. Yang dimaksud dengan tahap informasi adalah proses penjelasan, penguraian, atau pengarahan mengenai prinsipprinsip struktur pengetahuan, keterampilan, dan sikap. Tahap transformasi adalah proses peralihan atau perpindahan prinsip-prinsip struktur tadi ke dalam diri peserta didik. Proses transformasi dilakukan melalui informasi. Namun, informasi itu harus dianalisis, diubah, atau ditransformasikan ke dalam bentuk yang lebih abstrak atau konseptual agar dapat digunakan dalam konteks yang lebih luas. Dalam hal ini, peranan dan bantuan pengajar sangat diperlukan.

Pembelajaran adalah proses interaksi peserta didik dengan pendidik dan sumber belajar pada suatu lingkungan belajar. Pembelajaran merupakan bantuan yang diberikan pendidik agar dapat terjadi proses pemerolehan ilmu dan pengetahuan, penguasaan kemahiran, dan tabiat, serta pembentukan sikap dan kepercayaan pada peserta didik (Rahyubi, 2012: 3-4).

Menurut Pusat Angkatan Darat Amerika Serikat (US Army"s Center) dalam Suyono mendefinsikan hikmah pembelajaran sebagai pengetahuan yang diperoleh melalui pengalaman yang dikembangkan melalui saling berbagi, sehingga memberikan keuntungan pada yang lain. Setidaknya ada 3 (tiga) variabel yang perlu diperhatikan dalam aktivitas pembelajaran, yaitu: a. Variabel kondisi pembelajaran, yang meliputi karakteristik siswa, karakteristik bidang studi, kendala pembelajaran, dan tujuan instruksional.

b. Variabel metode pembelajaran, yang meliputi strategi pengorganisasian, strategi pengelolaan, dan strategi penyampaian pembelajaran.

c. Variabel hasil pembelajaran, yang meliputi efektivitas, efisiensi, dan daya tarik pembelajaran.

2. Tren Pembelajaran Abad 21

Tren pembelajaran Abad 21 adalah

4C ( Creative, Critical thinking, Communicative, dan Collaborative), Penguatan Pendidikan Karakter (PPK), HOTS (Higher Order of Thinking Skill), Gerakan Literasi Sekolah (GLS).

3. Model Make A Match

Model Make A Match (mencari pasangan) merupakan salah satu jenis dari metode dalam pembelajaran kooperatif. Model ini dikembangkan oleh Lorna Curran (1994). Model ini mampu memupuk kerja sama siswa dalam menjawab pertanyaan dengan mencocokkan kartu yang ada di tangan mereka, proses pembelajaran lebih menarik dan nampak sebagian besar siswa lebih antusias mengikuti proses pembelajaran, dan keaktifan siswa tampak sekali pada saat siswa mencari pasangan kartunya masing-masing.

Menurut Tarmizi dalam Mikran (2013: 11), Model Make A Match merupakan model belajar mengajar mencari pasangan dimana siswa mencari pasangan sambil belajar mengenai suatu konsep atau topik 
dalam suasana yang menyenangkan. Jumlah siswa dalam satu kelompok tidak boleh terlalu besar. hanya terdiri dari 2 orang atau lebih. Hal ini dimaksud agar proses kerjasama antar siswa berjalan efektif, sehingga memungkinkan semua siswa terlibat secara aktif dalam pemebelajaran untuk membahas dan memecahkan masalah. Dalam kelompok kecil itu siswa belajar dan bekersama sampai pada pengalaman belajar yang maksimal, baik yang bersifat pengalaman individual maupun kolektif sebagai pencerminan adanya prinsip-prinsip keaktifan siswa dalam pembelajaran.

\section{Pengertian Cooperative Learning}

Cooperative learning mengandung pengertian bekerja bersama dalam mencapai tujuan bersama. Dalam kegiatan kooperatif,mahasiswa secara individual mencari hasil yang menguntungkan bagi seluruh anggota kelompoknya. Jadi, belajar kooperatif adalah pemanfaatan kelompok kecil dalam pengajaran yang memungkinkan mahasiswa bekerja bersama untuk memaksimalkan belajar mereka dan belajar anggota lainnya dalam kelompok tersebut (Solihatin Etin,2007

\section{Model Jigsaw}

Model Jigsaw merupakan salah satu tipe model pembelajaran kooperatif yang terdiri dari tim-tim heterogen yang beranggotakan 4-5 orang siswa,materi pelajaran yang diberikan pada siswa dalam bentuk teks setiap anggota bertanggung jawab untuk mempelajari bagian tertentu bahan yang diberikan, dan mampu mengajarkan bagian tersebut kepada anggota lain La Iru dan La Ode Safiun Arihi (2012:61), Model
Jigsaw didesain untuk meningkatkan rasa tanggung jawab siswa terhadap pembelajarannya sendiri dan juga pembelajaran orang lain. Siswa tidak hanya mempelajari materi yang diberikan, tetapi mereka juga harus siap memberikan dan menjabarkan materinya tersebut kepada anggota kelompoknya yang lain.

6. Pembelajaran Geografi

Menurut Muhaimin pembelajaran adalah usaha membelajarkan siswa untuk belajar. Kegiatan pembelajaran akan melibatkan siswa mempelajari sesuatu dengan cara efektif dan efisien. Sedangkan geografi adalah ilmu yang mempelajari persamaan dan perbedaan fenomena geosfer dengan sudut pandang kelingkungan atau kewilayahan dalam konteks keruangan (Tika Pabundu 1997).

7. Hasil Belajar

Oemar Hamalik (2011: 89) mengatakan "Hasil belajar nampak sebagai terjadinya perubahan tingkah laku pada diri siswa yang dapat diamati dan terukur dalam bentuk perubahan pengetahuan, sikap dan keterampilan. Hal ini senada dengan Bloom seperti dikutip oleh Suharsimi Arikunto dalam bukunya yang berjudul Dasar-dasar Evaluasi Pendidikan (2012:117) membagi 3 macam hasil belajar menjadi 3 ranah, yaitu ranah kognitif, ranah afektif, ranah psikomotoris.

\section{METODOLOGI}

Penelitian ini dilakukan pada bulan November 2017 yang berlokasi di SMAN 3 Batusangkar. Penarikan sampel pada penelitian ini dilakukan secara Total Sampling. Jenis penelitian 
yang digunakan adalah Metode Eksperimen. Penelitian terdiri dari dua kelas yaitu kelas eksperimen dan kelas kontrol. Lokasi Penelitian tercantum pada peta 1. Sampel penelitian

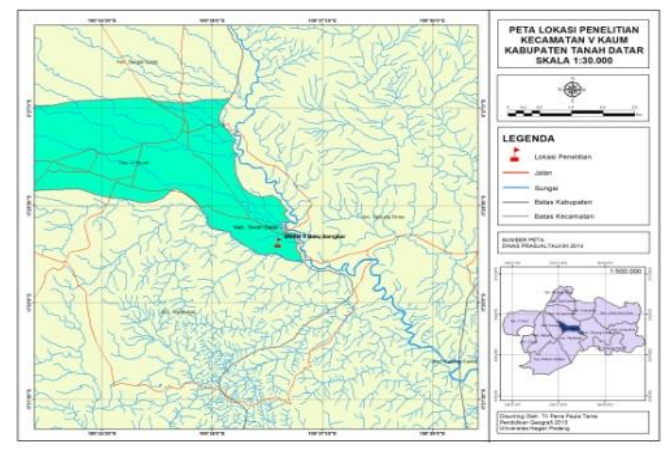

Peta 1. Sampel Penelitian

\section{Metode Penelitian}

Rancangan penelitian bisa dilihat pada tabel 1.

Tabel 1. Rancangan penelitian ini adalah sebagai berikut:

\begin{tabular}{|l|l|l|l|}
\hline Kelompok & Pretest & $\begin{array}{l}\text { Perlak } \\
\text { uan }\end{array}$ & $\begin{array}{l}\text { Tes } \\
\text { Akhir }\end{array}$ \\
\hline $\begin{array}{l}\text { Kelas } \\
\text { Eksperimen }\end{array}$ & Y1 & X1 & Y2 \\
\hline $\begin{array}{l}\text { Kelas } \\
\text { Kontrol }\end{array}$ & Y1 & X2 & Y2 \\
\hline
\end{tabular}

Keterangan :

X1 : Model Make A Match

X2 : Model Jigsaw

Y1 : Tes awal diberikan kepada kelas eksperimen dan kontrol

Y2 : Tes akhir diberikan kepada kelas eksperimen dan kontrol

Instrumen Penelitian

\section{Analisis Uji Coba}

Tes berbentuk objektif atau pilihan ganda,suatu tes dapat dikatakan baik jika mempunyai validitas, reliabilitas, indeks kesukaran, dan daya pembeda (Hamzah, B Uno,2008 : 110).

a. Validitas Tes
Menurut Sugiyono dalam Iskandar 2009 menyatakan instrument yang valid adalah instrument yang digunakan untuk mendapatkan data (mengukur) itu valid.

$r x y \frac{N \sum X Y-\left(\sum X\right)\left(\sum Y\right)}{\sqrt{N \cdot \sum X^{2}}-\left(\sum X\right)^{2}\left\{N \cdot \sum Y^{2}-\left(\sum Y\right)^{2}\right\}}$

\section{Sumber:Iskandar,2009}

Keterangan :

Rxy = angka indeks korelasi " $\mathrm{r}$ " Product moment

$\mathrm{N}=$ jumlah subjek penelitian

$\sum x=$ nilai dari $\mathrm{X}$ (skor tiap item)

$\sum Y=$ nilai $\mathrm{X}$ dari $\mathrm{Y}$ (skor total item)

$\sum X Y=$ jumlah hasil kali $\mathrm{X}$ dan $\mathrm{Y}$

Rxy $=$ Koefisien korelasi antara variabel $\mathrm{X}$ dan $\mathrm{Y}$ (indeks Validitas)

Kriteria uji: Butir tes dikatakan valid jika $r$ hitung $>r$ tabel pada $\alpha 0,05$ dan $\alpha 0.01$.

b. Reliabilitas Butir Soal

Reliabilitas berasal dari kata reliable, (Realiability) artinya dapat dipercaya. Sedangkan Reliabilitas artinya tingkat kepercayaan. Menurut Sugiyono (2014: 180) menyatakan bahwa Reliabilitas adalah tingkat atau derajat konsistensi dan suatu instrumen. Untuk mencari reliabilitas instrumen pilihan ganda atau yang skornya 1 dan 0 digunakan rumus $\mathrm{K}$ R sebagai berikut:

$r_{t t} \frac{k}{k-1}\left(\frac{S t^{2}-\sum p i q i}{S t^{2}}\right)$

Keterangan :

$\boldsymbol{r}_{\boldsymbol{t} \boldsymbol{t}}=$ reliabilitas instrumen

$\mathrm{k}=$ jumlah butir soal

$S_{t}^{2} \quad=$ Varians total 
$p_{\mathrm{i}}=$ Proporsi banyaknya subjek yang menjawab pada item 1

\section{$\mathrm{q}$ i $=1-\mathrm{pi}$}

Setelah diperoleh koefisien realibilitas kemudian dikonsultasikan dengan tabel $\mathrm{r}$ product moment dengan taraf signifikan $5 \%$. Jika harga $r_{11}>r_{\text {tabel}}$, maka instrumen dinyatakan reliabel

(Sugiyono,2014:180).

c. Tingkat Kesukaran Butir Soal Arifin (2012: 258) menjelaskan bahwa pengukuran tingkat kesukaran soal adalah pengukuran seberapa besar derajat kesukaran suatu soal.

$P \frac{\sum B}{N}$

Keterangan :

$\mathrm{P}=$ Tingkat kesukaran

$\sum B=$ Jumlah peserta didik yang menjawab benar

$\mathrm{N}=$ Jumlah peserta didik

Tabel 2. Kriteria Tingkat Kesukaran Butir Soal

\begin{tabular}{|l|l|l|}
\hline No. & Tingkat Kesukaran & Kriteria \\
\hline 1 & $\mathrm{P} \leq 0,33$ & Sukar \\
\hline 2 & $0,33<\mathrm{p}<0,67$ & Sedang \\
\hline 3 & $\mathrm{P} \geq 0,67$ & Mudah \\
\hline
\end{tabular}

Sumber : Syafri anwar,2009

d. Daya Pembeda Butir Soal

$$
\mathrm{DP}=\frac{B a}{l a}-\frac{B b}{l b}
$$

Keterangan :

DP =Daya Pembeda

$\mathrm{Ba}=$ Jumlah peserta didik yang menjawab benar dari kelompok atas

$\mathrm{Bb}=$ Jumlah peserta didik yang menjawab benar dari kelompok bawah

$\mathrm{Ja}=$ Jumlah peserta didik kelompok atas
$\mathrm{Jb}=$ Jumlah pserta didik kelompok bawah

Tabel 3. Kriteria Daya Pembeda

\begin{tabular}{|l|l|l|}
\hline No & Daya Pembeda & \multicolumn{1}{|c|}{ Kriteria } \\
\hline 1 & $>0,40$ & Sangat baik \\
\hline 2 & $>0,30-0,39$ & $\begin{array}{l}\text { Baik, tetapi } \\
\text { mungkin soal } \\
\text { perlu } \\
\text { peningkatan }\end{array}$ \\
\hline 3 & $0,20-0,29$ & $\begin{array}{l}\text { Sedang, Pada } \\
\text { umumnya dan } \\
\text { dibutuhkan dan } \\
\text { soal perlu } \\
\text { peningkatan }\end{array}$ \\
\hline 4 & $<0,19$ & $\begin{array}{l}\text { Buruk, ditolak } \\
\text { atau perlu } \\
\text { direvisi }\end{array}$ \\
\hline
\end{tabular}

Sumber: Arifin, 2012

2. Teknik Pengumpulan Data

Untuk teknik mengumpulkan data dalam penelitian ini penulis menggunakan teknik pengumpulan data sebagai berikut:

a. Menggunakan tes untuk melihat hasil belajar peserta didik

b. Menggunakan dokumentasi untuk mendapatkan informasi mengenai daftar nama peserta didik, jumlah peserta didik, dan perkembangan hasil belajar geografi, khususnya data yang menjadi kelas sampel penelitian.

3. Teknik Analisis Data

a. Metode Analisis Data Awal

1) Uji Normalitas Sampel

Uji normalitas sampel digunakan untuk mengetahui apakah data yang digunakan merupakan data yang berdistribusi normal atau tidak. Uji normalitas pada penelitian ini menggunakan rumus Uji Liliefors, yakni: 


$$
\mathrm{Zi}=\quad \frac{x i-x}{s}
$$

Keterangan :

$\mathrm{Xi}$ = Skor yang diperoleh siswa ke-i

$\mathrm{X}=$ Rata-rata skor

$\mathrm{S}$ = Simpangan Baku

Bandingkan nilai $\mathrm{L}_{0}<\mathrm{L}_{\text {tabel }}$ pada taraf nyata),0,5 kriteria pengujian $\mathrm{L}_{0}<\mathrm{L}_{\text {tabel }}$ maka data berdistribusi normal (Sugiyono,2014).

2) Uji Homogenitas Sampel

Uji homogenitas sampel digunakan untuk mengetahui apakah varians sampel-sampel yang diambil homogen. Uji homogenitas dilakukan dengan uji Varians. Untuk mempermudah dalam perhitungan maka satuan yang diperlukan dalam pengujian tes disusun sebagai berikut:

a) Mencari nilai varians terbesar dan varians yang terkecil dengan rumus:

$F_{\text {hitung }} \frac{\text { varians terbesar }}{\text { varians terkecil }}$ Sumber: Riduwan (2010:157)
Membanding

b) kan nilai $F_{\text {hitung }}$ dengan $F_{\text {tabel }}$ dengan rumus:

$\mathrm{dk}$ pembilang $=\mathrm{n}-1 \quad$ (varians terbesar), $\mathrm{dk}$ penyebut $=\mathrm{n}-1$ (varians terkecil)

Kriteria pengujian sebagai berikut:

Jika F hitung $\geq$ F tabel, berarti tidakhomogen.

Jika $\mathrm{F}$ hitung $\leq \mathrm{F}$ tabel, berarti homogen.

b.

Metode

Analisis Data Akhir

Metode analisis data akhir yang akan dilakukan yakni menguji hipotesis dengan uji-t atau t-tes, Uji-t atau, digunakan untuk menguji perbedaan rata nilai untuk dua buah sampel data harus normal dan homogen.

$$
\mathrm{t}=\quad \frac{x 1-x 2}{s \sqrt{\left\{\frac{1}{n_{1}}+\frac{1}{n_{2}}\right\}}}
$$

Dengan:

$\sqrt{s^{2}} \frac{\left(\mathrm{n}_{1}-1\right) s_{1}^{2}+\left(\mathrm{n}_{2}-1\right) s_{2}^{2}}{\mathrm{n}_{1}+\mathrm{n}_{2}-2}$

Sumber : Syafril (2010:208)

Keterangan :

$\mathrm{X}_{1}=$ Nilai rata-rata kelompok pertama

$\mathrm{X}_{2}=$ Nilai rata-rata kelompok kedua

$S_{1=}^{2}$ Varians skor kelompok pertama

$S_{2}^{2}=$ Varians skor kelompok kedua

$\mathrm{n}_{1}=$ Banyaknya skor yang memiliki subjek kelompok pertama

$\mathrm{n}_{2}=$ Banyaknya skor yang memiliki subjek kelompok kedua

$\mathrm{S}=$ Standar Deviasi Gabungan

Kriteria pengujian yaitu jika $t_{\text {tabel }} \leq$

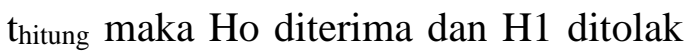
pada taraf nyata $\alpha=0,05$, sedangkan, $t_{\text {hitung }} \geq t_{\text {tabel }}$ maka Ho ditolak dan $\mathrm{H} 1$ diterima. Jika dapat disimpulkan bahwa data yang diperoleh ada perbedaan yang signifikan.

\section{HASIL DAN PEMBAHASAN}

\begin{tabular}{|c|l|c|}
\hline Kriteria & Nomor Item Soal & Jumlah \\
\hline Valid & $1,2,3,5,6,8,9,11,12$, & 30 \\
& $13,15,16,17,19,21,2$ & \\
& $2,23,25,26$ & \\
& $27,28,29,31,32,34,3$ & \\
& $5,36,37,38,39$ & \\
\hline Tidak & $4,7,10,14,18,20,24$, & 10 \\
Valid & $30,33,40$ & \\
\hline
\end{tabular}

1. Uji Coba Instrumen Soal

a. Validitas Soal

Tabel 4. Hasil Validitas Butir Soal 
Sumber : Data pengolahan primer 2017

Berdasarkan tabel diatas terdapat 30 butir soal yang valid dan 10 soal

\begin{tabular}{|l|l|c|}
\hline Kriteria & Nomor Item Soal & Jumlah \\
\hline Soal & $1,2,3,5,6,8,9,11,12$, & 30 \\
yang & $13,15,16,17,19,21$, & \\
dipakai & $22,23,25,26,27,28$, & \\
& $29,31,32,34,35,36$, & \\
& $37,38,39,40$ & \\
\hline $\begin{array}{l}\text { Soal } \\
\text { yang }\end{array}$ & $4,7,10,14,18,20,24$, & 10 \\
dibuang & $30,33,40$ & \\
\hline
\end{tabular}

yang tidak valid.

b. Reliabilitas Butir Soal

$r_{\mathrm{tt}} \frac{k}{k-1}\left(\frac{S t^{2}-\sum p i q i}{S t^{2}}\right)$

$$
\frac{40}{40-1}\left(\frac{53,39-7,0794}{53,39}\right)
$$

\begin{tabular}{|l|l|l|}
\hline Kriteria & \multicolumn{1}{|c|}{ Nomor Item Soal } & \multicolumn{1}{|c|}{$\begin{array}{c}\text { Jumla } \\
\text { h }\end{array}$} \\
\hline Sukar & 6,40 & 2 \\
\hline Sedang & $1,2,3,5,8,9,11,12,13,1$ & 33 \\
& $5,16,17,19,21,22,23,2$ & \\
& $5,26,27$, & \\
& $28,29,31,32,34,35,36$, & \\
& $37,38,39$ & \\
\hline Mudah & $4,7,10,14,24$ & 5 \\
\hline
\end{tabular}

$=0,890$ (Reliabel), $\mathrm{r}$ tabel 0,396

c. Tingkat Kesukaran Butir Soal

Tingkat kesukaran butir soal dapat dilihat pada Tabel.5.

\begin{tabular}{|l|l|l|}
\hline Kriteria & \multicolumn{1}{|c|}{ Nomor Item Soal } & Jumlah \\
\hline $\begin{array}{l}\text { Sangat } \\
\text { Baik }\end{array}$ & $\begin{array}{l}5,6,8,12,13,15,21,22, \\
26,29,32,37,38,39\end{array}$ & 14 \\
\hline Baik & $\begin{array}{l}1,3,9,11,16,17,19,23, \\
25,27,28,31,35,36\end{array}$ & 14 \\
\hline Sedang & 2,34 & 2 \\
\hline Buruk & $\begin{array}{l}4,7,10,14,18,20,24,30 \\
\end{array}$ & 10 \\
\hline
\end{tabular}

Tabel 5. Hasil Tingkat Kesukaran Butir Soal
Sumber : Data pengolahan primer 2017

d. Daya Pembeda Butir Soal

Tabel 6. Hasil Daya Pembeda Butir Soal

Sumber : Data pengolahan primer 2017

e.

Hasil

Analisis Soal Uji Coba

Tabel 7. Hasil Analisis Soal Uji Coba

Sumber : Data pengolahan primer 2017

2. Hasil belajar pada Kelas Eksperimen Menggunakan Model Make A Match

Tabel 8. Distribusi Frekuensi Data Hasil Belajar Siswa Kelas Eksperimen

\begin{tabular}{|c|c|c|}
\hline $\begin{array}{c}\text { Kelas } \\
\text { Interval }\end{array}$ & $\begin{array}{c}\text { Frekuensi } \\
(\mathbf{f 0})\end{array}$ & $\begin{array}{c}\text { Frekuensi } \\
(\boldsymbol{\%})\end{array}$ \\
\hline $70-74$ & 2 & 8 \\
\hline $75-79$ & 2 & 8 \\
\hline $80-84$ & 9 & 36 \\
\hline $85-89$ & 6 & 24 \\
\hline $90-94$ & 5 & 20 \\
\hline $95-99$ & 1 & 4 \\
\hline
\end{tabular}

Sumber: Data pengolahan Primer 2017

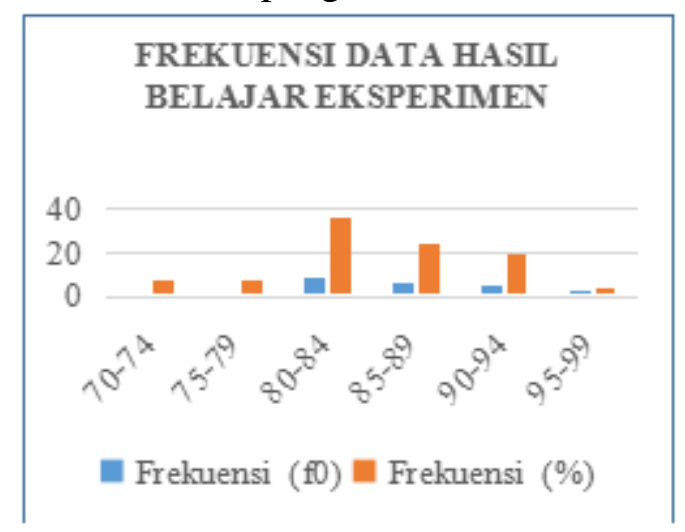

Sumber: Data pengolahan Primer 2017 Gambar 1.Histogram Data Hasil Belajar Siswa Kelas Eksperimen

Dari Tabel 8 dan Gambar 1 terlihat data hasil belajar mata pelajaran Geografi siswa Kelas Ekperimen dengan nilai terendah 70 dan nilai 
tertinggi 97. Nilai hasil belajar 25 orang siswa Kelas Eksperimen termasuk kategori 'cukup' (70-79) 4 orang, yang termasuk kategori 'baik' (80-89) 15 orang, dan termasuk kategori 'sangat baik' (90-99) adalah 6 orang. Pesertadidik yang mendapat nilai tertinggi berada di interval 80-84 sebanyak 9 orang, dan yang berada di atas KKM 78 adalah 22 orang (88\%) artinya, Hasil belajar mata pelajaran Geografi siswa kelas eksperimen menggunakan Model Make A Match di SMA Negeri 3 Batusangkar, termasuk kategori 'sangat baik'.

3. Hasil Belajar Pada Kelas Kontrol Menggunakan Model Jigsaw

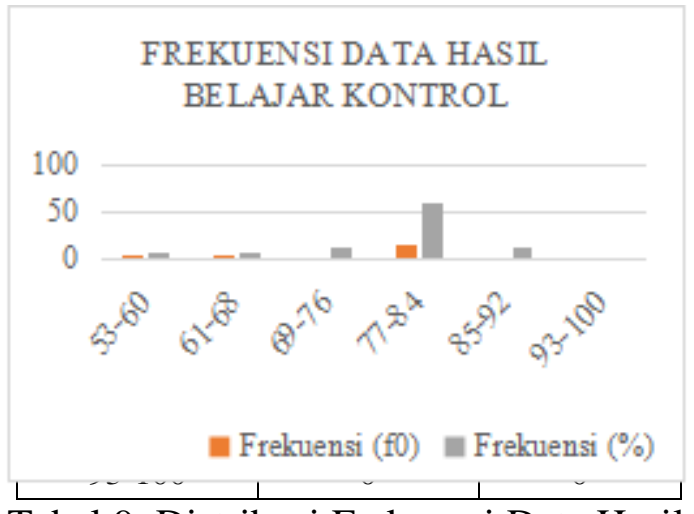

Tabel 9. Distribusi Frekuensi Data Hasil Belajar Siswa Kelas Kontrol

Sumber : Pengolahan Data Primer 2017

Gambar 2. Histogram Data Hasil Belajar Siswa Kelas Kontrol

Dari Tabel 9 dan Gambar 2 terlihat data hasil belajar mata pelajaran Geografi siswa kelas kontrol dengan nilai terendah 53 dan nilai tertinggi 90 . Nilai hasil belajar 25 orang siswa kelas kontrol termasuk kategori 'cukup' (5368) 4 orang, yang termasuk kategori 'baik' (69-84) 18 orang, dan termasuk kategori 'sangat baik' (85-100) adalah 15 orang. Dilihat dari nilai hasil belajar 25 orang siswa kelas kontrol yang berada di atas KKM 78 adalah 15 orang (60\%), artinya hasil belajar mata pelajaran Geografi siswa kelas kontrol menggunakan Model Jigsawdi SMA Negeri 3 Batusangkar,termasuk kategori 'baik'.

4.
\begin{tabular}{|l|c|c|}
\hline \multicolumn{1}{|c}{ Variabel } & \multicolumn{2}{c}{ Kerbandingan } \\
\cline { 2 - 3 } & $\begin{array}{c}\text { Kelas } \\
\text { Eksperimen } \\
\text { (X.IPS 2) }\end{array}$ & $\begin{array}{c}\text { Kelas } \\
\text { Kontrol } \\
\text { (X.IPS 1) }\end{array}$ \\
\hline $\begin{array}{l}\text { N-Jumlah } \\
\text { sampel }\end{array}$ & 25 & 25 \\
\hline Skor tertinggi & 97 & 90 \\
\hline Skor terendah & 70 & 53 \\
\hline Jumlah Nilai & 2107 & 1930 \\
\hline X rata-rata & 84 & 77 \\
\hline SD & 40,627 & 77,833 \\
\hline SD & 1650,553 & 6057,975 \\
\hline
\end{tabular}

Belajar menggunakan Model Make A

Match dengan Model Jigsaw.

Tabel 10. Hasil Perhitungan Mean dan Varians

Sumber : Pengolahan Data Primer 2017

5. Uji Persyaratan Analisis

a. Uji Normalitas

Tabel 11. Hasil Uji Normalitas

\begin{tabular}{|l|c|}
\hline \multicolumn{1}{|c|}{ Variabel } & Lhitung \\
\hline Hasil Belajar Kelas & 0,121 \\
Eksperimen dan & 0,184 \\
Kelas Kontrol & \\
\hline
\end{tabular}

Sumber: Data pengolahan Primer 2017

Untuk kelas Eksperimen rumus Hasil Uji Normalitas menggunakan rumus Liliefors menemukan Lhitung 0,121. Jika dibandingkan dengan Ltabel 0.396 taraf signifikan 0,05. Untuk kelas Kontrol rumus Hasil Uji Normalitas menggunakan rumus Liliefors menemukan bahwa Lhitung 0,184 jika 
dibandingkan dengan Ltabel 0,396 taraf signifikan 0,05. Lhitung < Ltabel $(0,184<0,396)$. Dengan demikian dapat disimpulkan bahwa data berasal dari kelompok yang berdistribusi normal.

b.

Uji

Homogenitas

Tabel 12. Hasil Uji Homogenitas

\begin{tabular}{|l|c|c|}
\hline \multicolumn{1}{|c|}{ Variabel } & Fhitung & Ftabel \\
\hline Kelas & 1,916 & 1,98 \\
Eksperimen & & \\
dan Kelas & & \\
Kontrol & & \\
\hline
\end{tabular}

Sumber: Data pengolahan Primer 2017

Jadi dapat disimpulkan

Fhitung < Ftabel $\quad(1,916<1,98), \quad$ maka terima Ho (Varians Data Homogen).

6.

Uji

Hipotesis

Tabel 12. Hasil Pengujian Data Nilai Post Test menggunakan Uji-t

\section{Pembahasan}

Hasil penelitian ini bertujuan untuk melihat pengaruh penerapan Model Make A Match terhadap hasil belajar siswa pada mata pelajaran Geografi kelas X IPS di SMA Negeri 3 Batusangkar. Jumlah Populasi dalam penelitian ini adalah sebanyak 50 siswa dengan menggunakan sampel penelitian sebanyak 50 orang yang terdiri dari dua kelas sampel peneltian yaitu kelas X.IPS 2 sebagai kelas Eksperimen dan kelas X.IPS 1 sebagai kelas kontrol.

Pada masing-masing kelas mendapat empat kali pertemuan dengan perlakuan yang berbeda setelah diterapkan metode pembelajaran yang berbeda pada kedua kelas maka tahap selanjutnya adalah melakukan pengambilan data untuk dianalisis dengan menggunakan post test untuk melihat hasil belajar. Setelah diperoleh hasil post test maka dilakukan uji prasyarat analisis yang bertujuan untuk

\begin{tabular}{|c|c|c|c|c|c|c|c|}
\hline Kelas & $\mathrm{N}$ & Mean & Sgab & Dk & $t_{\text {hitung }}$ & $t_{\text {tabel }}$ & Kesimpulan \\
\hline Eksperimen & 25 & $\mathbf{8 4 , 2 8}$ & $\mathbf{7 , 6 9 6}$ & 48 & $\mathbf{3 , 2 9 3}$ & $\mathbf{2 , 0 2 1}$ & $H_{1}$ \\
\hline Kontrol & 25 & 77,2 & 7,696 & 48 & 3,293 & 2,021 & $H_{1}$ \\
\hline
\end{tabular}

Sumber: Data pengolahan Primer 2017

Berdasarkan tabel diatas,

diperoleh nilai $\quad t_{\text {hitung }}=t_{\text {tabei }}$ dengan taraf nyata 0,05 dan derajat kebebasan 48 maka

$\mathrm{H}_{\text {omenolak }}$ dan menerima $\quad \mathrm{H}_{1}$, Hal ini berarti terdapat perbedaan hasil belajar Geografi siswa kelas X. IPS SMA Negeri 3 Batusangkar yang signifikan antara menggunakan penerapan ModelMake A Match dengan yang menggunakan ModelJigsaw. menentukan rumus yang digunakan dalam menguji hipotesis dalam uji ini dilakukan uji normalitas dan uji homogenitas.

Pengujian hipotesis data digunakan uji t-test. Berdasarkan hasil perhitungan menggunakan uji-t diperoleh yang signifikan diperoleh nilai $\quad t_{\text {hitung }}=t_{\text {tabei }}$ dengan taraf nyata 0,05 dan derajat kebebasan 48 maka $H_{0}$ menolak dan menerima $H_{1}$, Hal ini berarti terdapat 
perbedaan hasil belajar Geografi siswa kelas X. IPS SMAN 3 Batusangkar yang signifikan antar menggunakan penerapan model Make A Match dengan yang menggunakan model Jigsaw. Pernyataan mengenai hipotesis penelitian ini di perkuat dengan pernyataan beberapa siswa kelas eksperimen yang peneliti wawancarai untuk membuktikan bahwa meningkatnya nilai siswa memang karena penerapan model Make A Match dalam pembelajaran. Dari hasil wawancara tersebut dapat diambil kesimpulan bahwa belajar dengan Make A Match membuat siswa senang dan merasa bahagia, karena dengan mencocokkan pertanyaan dan jawaban ini siswa bertanggung jawab pula dengan pertanyaan dan jawaban yang di pasangkan.

Memang tidak secara keseluruhan Make A Match mempengaruhi hasil belajar siswa, siswa mengikuti bahwa faktor guru serta model mengajar yang digunakan guru juga sangat mempengaruhi dari hasil belajar. Sesuai dengan teori John b. Watson, Teori Behaviorisme adalah input yang berupa stimulus dan output yang berupa respons. Stimulus adalah apasaja yang diberikan guru kepada siswa, sedangkan respons adalah reaksi atau tanggapan siswa terhadap stimulus yang diberikan oleh guru tersebut (Rahyubi.2012). Jadi, Model pembelajaran yang menginginkan siswa untuk aktif dikelas ini sangat baik sekali membuat siswa aktif dan selektif dalam menjawab pertanyaan, apabila ada pertanyaan siswa yang menyimpang atau keliru siswa merasa ada keharusan untuk bertanya pada guru atau siswa yang bersangkutan membuat soal. Jadi dapat menyimpulkan bahwa hasil belajar tidak semuanya tergantung kepada model pembelajaran namun faktor guru dalam mengajar dan pemilihan model pembelajaran yang tepat sangat berpengaruh terhadap hasil belajar. Hal ini juga telah dibuktikan oleh Nofrion (2017;15-19) dalam penelitiannya yang mengungkapkan peran guru dalam pembelajaran dengan menggunakan soal-soal tingkat tinggi mampu meningkatkan aktivitas belajar siswa secara signifikan.

Adapun kelebihan yang didapat menggunakan model pembelajaran ini, Dapat meningkatkan aktivitas belajar siswa, baik secara kognitif maupun fisik Karena ada unsur permainan, maka model pembelajaran ini menyenangkan. Meningkatkan pemahaman siswa terhadap materi yang dipelajari dan dapat meningkatkan motivasi belajar siswa. Efektif sebagai sarana melatih keberanian siswa untuk tampil presesntasi. Efektif melatih kedisiplinan siswa menghargai waktu untuk belajar.

Adapun kelemahan model pembelajaran Make A Match adalah Jika modelpembelajaran ini tidak dipersiapakan dengan baik, akan banyak waktu yang terbuang.Pada awal penerapan model pembelajaran ini, banyak siswa yang akan malu berpasangan dengan lawan jenisnya. Jika guru tidak mengarahkan siswa dengan baik, akan banyak siswa yang kurang memperhatikan pada saat presentasi pasangan. Guru harus hatihati dan bijaksana saat memberi hukuman pada yang tidak mendapatkan 
pasangan, karena mereka bisa malu. Menggunakan model pembelajaran ini secata terus-menerus akan menimbulkan kebosanan.Sementara itu, kelas yang belajar dengan menggunakan model Jigsaw. Ramainya kondisi kelas menjadi tidak kondusif. Pembelajaran kooperatif tipe Jigsaw masih baru dan Siswa menjadi bingung dengan keramaian di kelas. Ketergantungan siswa pada temannya membuat Siswa yang lemah memungkinkan menggantungkan pada siswa yang pandai.

Berdasarkan hasil penelitian diatas, dapat dilihat bahwa model Make A Match dapat menjadi alternative dalam menerapkan variasi metode pembelajaran, hal ini terbukti dengan menggunakan model ini dapat memberikan pengaruh yang baik dalam meningkatkan hasil belajar geografi siswa.

\section{PENUTUP}

\section{Kesimpulan}

Berdasarkan hasil analisis yang telah dijelaskan pada bab terdahulu mengenai (kelas eksperimen) perbedaan hasil belajar yang menggunakan Model Make A Match dan Model Jigsaw pada kelas (kontrol) maka dapat diambil kesimpulan bahwa Rata-rata hasil belajar geografi siswa pada kelas eksperimen yang belajar menggunakan Model Make A Match yaitu (84) lebih tinggi jika dibandingkan dengan rata-rata hasil belajar siswa kelas kontrol yang menggunakan Model Jigsaw yaitu (77). Proses pembelajaran Geografi dengan menggunakan Model Make A
Match Dapat meningkatkan aktivitas belajar siswa, baik secara kognitif maupun fisik Karena ada unsur permainan, maka metode pembelajaran ini menyenangkan. Meningkatkan pemahaman siswa terhadap materi yang dipelajari dan dapat meningkatkan motivasi belajar siswa. Hasil Uji Hipotesis diperoleh diperoleh nilai $t_{\text {hitung }}=t_{\text {tabei }}$ dengan taraf nyata 0,05 dan derajat kebebasan 48 maka $\mathrm{H}_{0 \text { menolak }}$ dan menerima $\mathrm{H}_{1}$, Hal ini berarti terdapat perbedaan hasil belajar Geografi siswa kelas X. IPS SMA Negeri 3 Batusangkar yang signifikan antara menggunakan penerapan Model Make A Match dengan yang menggunakan Model Jigsaw. Berdasarkan penjelasan diatas jadi dapat disimpulkan Model Make A Match dapat menjadi alternative dalam pembelajaran dan berpengaruh terhadap hasil belajar siswa dibandingkan dengan Model Jigsaw di SMA Negeri 3 Batusangkar.

\section{Saran}

Berdasarkan kesimpulan diatas, dikemukakan sarn-saran sebagai berikut:

a. Penggunaan Model pembelajaran Make A Match dapat dijadikan salah satu cara dalam meningkatkan hasil belajar geografi.

b. Bagi peneliti selanjutnya disarankan agar melakukan penelitian terkait dengan membandingkan model pembelajaran lainnya. 
c. Bagi guru-guru baiknya diadakan seminar atau workshop mengenai metode-metode pembelajaran dalam mengajar agar murid timbul rasa senang dan bahagia serta tertarik untuk terus bersemangat belajar agar berpengaruh terhadap hasil belajar.

\section{DAFTAR KEPUSTAKAAN}

Arikunto, Suharsimi. 2012. Dasardasar Evaluasi Pendidikan Edisi 2. Jakarta: Bumi Aksara.

Arifin, Zainal. 2012. Penelitian Pendidikan.PT Remaja

Rosdakarya Offset: Bandung.

Hamzah B. Uno.2008.Teori Motivasi dan Pengukurannya Analisis di Bidang Pendidkan. Jakarta: PT Bumi Aksara.

Hamalik Oemar.2011.Kurikulum dan Pembelajaran. Jakarta: Bumi Aksara.

Iskandar.2009.Metodologi Penelitian Pendidikan dan Sosial.Jakarta: GP Press

Lie,Anita.2004.Cooperative Learning : Mempraktikan

Cooperative

Learning Di Ruang-ruang Kelas.Jakarta : PT Grasindo.

La Iru,La Ode Safiun Arihi.2012.Analisis Penerapan Pendekatan,Metode,Strategi,dan Model-model Pembelajaran. Jakarta: Multi Presindo.

Mikran.2013.Penerapan Model Pembelajaran Kooperatif Make A Match Untuk Meningkatkan Hasil Belajar Siswa Kelas VIIA SMP Negeri 1 Tomini Pada Konsep
Gerak.Jurnal Pendidikan Fisika Tadulako.Vol.2.No.2

Napsiah,Indah Sari.2016. Komparasi Hasil Belajar Siswa Antara Metode Ceramah dan Model Snowball Trowing Pada Mata Pelajaran IPS Geografi di Kelas $\begin{array}{lll}\text { VII } & \text { SMP Negeri } 17\end{array}$ Padang.Skripsi UNP

Nofrion. 2017. Peningkatan Aktivitas Belajar Siswa Melalui Penerapan Metode Jumping Task pada Pembelajaran Geografi. E_Journal Geografi UNIMED.Volume 9, Nomor 1 tahun 2017. Hal 11-20.

Rusman.2010.Model-model

Pembelajaran.Jakarta : $\quad$ PT

RajaGrafindo Persada.

Riduwan.2010.Belajar

Mudah

Penelitian Untuk Guru, Karyawan dan Peneliti Pemula.Bandung : Alfabeta.

Rahyubi,Heri.2012.Teori-teori Belajar dan Aplikasi Pembelajaran Motorik.Bandung: Nusa Media

Solihatin Etin, Raharjo.2007. Cooperative Lerarning.Jakarta : Bumi Aksara.

Syafri Anwar.2009.Penilaian Berbasis

Kompetensi.Padang.Unp Press

Syafril.2010.Statistik. Padang : Suka Bina Press.

Suyono,dkk.2014.Belajar dan Pembelajaran.Bandung: PT Remaja Rosdakarya.

Sugiyono.2014.Metode Penelitian Kombinasi (Mixed Methods). Bandung: Alfabeta.

Tika Pabundu.1997. Metode Penelitian Geografi. Jakarta: PT Gramedia Pustaka Utama. 
Undang-undang No.20 tahun 2003 pasal 1 ayat (1) tentang Sistem Pendidikan Nasional

Undang-undang No.14 tahun 2005 tentang Guru dan Dosen pasal 4 